\title{
New pollen records of Late Pleistocene and Holocene changes of environment and climate in the Lower Amur River basin, NE Eurasia
}

\author{
V.B. Bazarova ${ }^{\mathrm{a}, *}$, M.A. Klimin ${ }^{\mathrm{b}}$, L.M. Mokhova ${ }^{\mathrm{a}}$, L.A. Orlova ${ }^{\mathrm{c}}$ \\ ${ }^{a}$ Pacific Institute of Geography FEB RAS, Radio Street 7, Vladivostok 690041, Russia \\ ${ }^{\mathrm{b}}$ Institute of Aquatic and Ecological Problems FEB RAS, Kim Yu Chen Street 65, Khabarovsk 680063, Russia \\ ${ }^{\mathrm{c}}$ Institute of Geology and Minerology SB RAS, Koptyuk Street 3, Novosibirsk 630090, Russia
}

Available online 12 September 2007

\begin{abstract}
The Late Pleistocene-Holocene paleoclimate and paleoenvironmental changes of the Lower Amur Basin are presented based on pollen records from radiocarbon dated peat sections. The Gur section represents the most complete terrestrial record of the Russian Far East, and probably for all of Northeast Asia. Landscape changes are reconstructed for warm events, corresponding to the Bølling and Allerød, and cold episodes as Middle Dryas and Younger Dryas in Europe. There were three warm periods in the Lower Amur basin: 8900-8300, 5000-5700 and 3200-4200 BP. A major expansion of diverse species in the forest formations in the entire Lower Amur River basin occurred at 5000-5700 BP. Changes and developments of paleoclimate events and paleoenvironmental changes of Late Pleistocene and Holocene in Lower Amur basin were correlative with European climate events.
\end{abstract}

(C) 2007 Elsevier Ltd and INQUA. All rights reserved.

\section{Introduction}

The relatively continuous accumulation of peat allows reconstruction of climate changes and establishing detailed paleogeographic boundaries in the late Pleistocene and the Holocene. Studies of the Holocene environments in the southern continental part of the Russian Far East in general are limited due to lack of long terrestrial records such as peat bogs. The first data by reconstruction of paleoenvironment were published in the 1930s (Kushev, 1936; Minkina et al., 1936). Until recently, most of studied peat sections in the Lower Amur River basin were not radiocarbon-dated (Veinbergs et al., 1976; Sokhina et al., 1978; Korotky and Lobanova, 1983; Mikishin et al., 1987). Recently, more detailed data became available for the middle part of Lower Amur River basin (Korotky, 2002; Klimin et al., 2004). This paper presents new data on the late Pleistocene and Holocene paleoenvironmental changes in the entire Lower Amur River basin.

\footnotetext{
*Corresponding author.

E-mail address: bazarova@tig.dvo.ru (V.B. Bazarova).
}

\section{Regional setting}

The Lower Amur River basin, about $1000 \mathrm{~km}$, is situated between $48^{\circ}$ and $54^{\circ} \mathrm{N}$. This basin is the largest peat accumulation area in the Russian Far East. Peat bogs cover about $58000 \mathrm{~km}^{2}$ (Prozorov, 1974). The northern part of the basin is located in the lacustrine-alluvial Udyl-Kizi depression, and the southern part in the Middle Amur depression. These depressions are different both in natural conditions and dimensions. The climate is temperate with monsoon influence. During the cold season, meridional circulation with a northern component predominates and brings dry and cold air. In summer, southerly meridional circulation is typical (Vitvitsky, 1969). The coldest month is January $\left(-22\right.$ to $\left.-27^{\circ} \mathrm{C}\right)$ and July $\left(16-18^{\circ} \mathrm{C}\right)$ is the warmest. As much as $80-90 \%$ of annual precipitation occurs in summer. Average annual precipitation ranges from 450 to $550 \mathrm{~mm}$ in the southern part of Lower Amur basin to $700-1200 \mathrm{~mm}$ in mountainous areas and coastal areas adjacent to the Sea of Japan and Okhotsk Sea. The coefficient of humidity fluctuates from 1.4 to 2.8 and characterizes this territory as sufficiently wet and favorable for development of bogs (Petrov et al., 2000). 


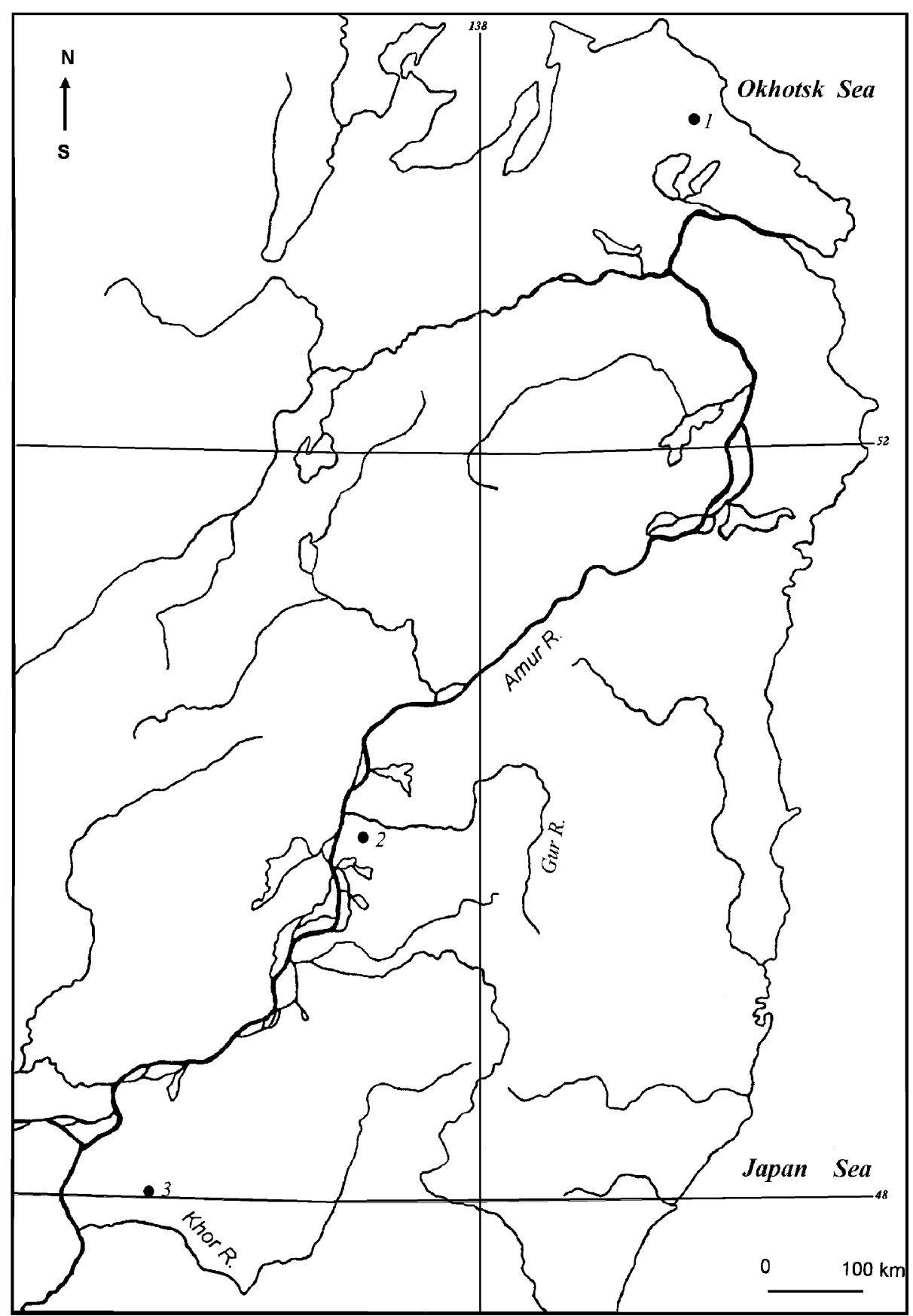

Fig. 1. Study area, showing location of investigated exposures: 1: Tyapka; 2: Gur; 3: Kiya.

There are three forest zones in Lower Amur River basin-light coniferous larch forests in the northern part, dark coniferous forests in the middle part, and mixed coniferous broad-leaved forests in the southern part. Three peat sections located in these forest zones were studied (Fig. 1).

\section{Materials and methods}

Excavated sections of peat were sampled for pollen and botanical composition analysis at $5 \mathrm{~cm}$ intervals. Slices of peat 5 -cm thick were collected for ${ }^{14} \mathrm{C}$ dating. In some sapropel samples from the basal part of the Gur section and the underlying clay samples of the Kiya section, diatom assemblages were studied.

\subsection{Pollen analysis}

Pollen was extracted following routine procedures (Sladkov, 1967) and 700-800 grains were counted. The percentage of palynomorphs for tree groups, represented by arboreal pollen (AP), non-arboreal pollen (NAP) and 
spores, was estimated for each sample, assuming that total amount of pollen of the main genera was counted as a percentage within each group, assuming that the total amount in each group is $100 \%$.

\subsection{Chronology}

For two sections, radiocarbon dates were determined in the Institute of Geology and Mineralogy SB RAS (Lab. index SOAN). Peat samples were cleaned by acid/alkali/ acid, then decalcified using $3 \% \mathrm{HCl}$ solution, and the humid fraction was extracted using $1 \mathrm{~N} \mathrm{NaOH}$. The extracted matter was acidified to $\mathrm{pH} 1$ with dilute $\mathrm{HCl}$ to recover the humic fraction. The ${ }^{14} \mathrm{C}$ activity was measured by liquid scintillation counting. For the Gur section, plant remains were picked for AMS ${ }^{14} \mathrm{C}$ dating Arizona University (Lab. index is AA) using a standard acid/ alkali/acid pretreatment. Afterwards, plant remains were used for $\mathrm{CO}_{2}$ gas preparation according to a routine procedure.

\section{Results and interpretation}

\subsection{Tyapka section}

The Tyapka section $\left(53^{\circ} 42^{\prime} \mathrm{N}, 140^{\circ} 07^{\prime} \mathrm{E}\right.$; $4 \mathrm{~m}$ a. s. 1.) is located near the Sakhalin Bay coast (Okhotsk Sea) and is the northernmost section in the Lower Amur River basin. This area is situated in the southern edge of the light coniferous larch forest. The thickness of the continuous peat deposits is $5.4 \mathrm{~m}$. In general the peat bog is formed from sphagnum-grass and sphagnum-tree peat. The degree of decomposition of peat is $15-25 \%$ in the upper part and $40-60 \%$ in the low part of the section. The results of pollen analysis are shown in Fig. 2.

Zone I. 10 000-9300 BP $(540-490 \mathrm{~cm})$. The lower part of the section (depth $535-530 \mathrm{~cm}$ ) was dated at $9975 \pm 120 \mathrm{BP}$ (SOAN-4025). The AP group dominates all assemblages; Betula (especially, shrub birch) and Alnaster are present at 56 and $35 \%$ correspondingly. The number of coniferous species pollen is low (to $6 \%$ ). The composition of NAP is $20 \%$, and spores is $10 \%$. This peat layer began to accumulate in cold climate conditions.

Zone II. 9300-8000 BP $(490-430 \mathrm{~cm})$. The pollen assemblages of the lower part are characterized by the first appearance of broad-leaved pollen (Ulmus, Quercus and Juglans, to 3\%), decrease of shrub birch pollen and increase of coniferous species pollen (Picea sect. Omorica to $8 \%$; Larix to $4 \%$; and the first appearance of Abies to $0.6 \%)$. This part of the peat layer was accumulated in temperate warm climate conditions. In the upper part of this layer, shrub birch pollen increases (to 56\%), and broad-leaved species disappeared. This peat was formed during strong cooling.

Zone III. $8000-5000 \mathrm{BP}(430-290 \mathrm{~cm})$. The horizon $415-420 \mathrm{~cm}$ was dated at $7720 \pm 100 \mathrm{BP}$ (SOAN-4024). The assemblages in the lower part of the peat layer are characterized by appearance of broad-leaved pollen (Ulmus and Quercus - to 6\%), increase in Pinus s/g Haploxylon, probably Pinus koraiensis (to 7\%) and by a decrease in the abundance of Betula sect. Nanae, Alnaster, and Alnus pollen (to $12 \%$ ). The middle part of the layer $(350-355 \mathrm{~cm})$ was dated at $6240 \pm 100 \mathrm{BP}$. It is characterized by a higher abundance of dark coniferous species. The assemblages of the upper part $(330-290 \mathrm{~cm})$ consist of the greatest number of broad-leaved pollen (Quercus - to 5\%, Ulmus to $3 \%$, Corylus - to $1 \%$ and single Juglans). The horizon $300-305 \mathrm{~cm}$ was dated at $5325 \pm 95$ (SOAN-4022). The composition of the pollen assemblages reflects warm climate conditions in the early Zone III, somewhat cooler conditions in the middle part of this zone and the warmest conditions in the upper part.

Zone IV. 5000-2500 BP $(290-170 \mathrm{~cm})$. At this depth the composition of pollen assemblages changes very significantly. Coniferous species dominate (to $50 \%$ ) in the assemblage of the lower part of the interval. The birch pollen increased (to 94\%), especially Betula sect. Nanae (to $47 \%$ ). The presence of Larix pollen (to $7.5 \%$ ) is noticeable. The upper part of the layer is characterized by appearance of broad-leaved species (Quercus - to 3.5\%, Ulmus - to $1.6 \%$ and single Corylus) and presence of Pinus $\mathrm{s} / \mathrm{g}$ Haploxylon pollen, probably Pinus koraiensis (to 10\%). The ${ }^{14} \mathrm{C}$ date $3510 \pm 60 \mathrm{BP}$ (SOAN-4044) at $250-255 \mathrm{~cm}$ constrains the age of this interval. The low part of Zone IV corresponds to significant cooling and the upper part to warmer climate conditions.

Zone $V$. 2500-0 yr BP $(170-0 \mathrm{~cm})$. Three ${ }^{14} \mathrm{C}$ dates constrain the age of this layer: $2480 \pm 70 \mathrm{BP}$ (SOAN-4163) at $165-170 \mathrm{~cm}, 2025 \pm 100 \mathrm{BP}(\mathrm{SOAN}-4162)$ at $125-130 \mathrm{~cm}$ and $1395 \pm 60 \mathrm{BP}(\mathrm{SOAN}-4017)$ at $45-50 \mathrm{~cm}$. The assemblages in the lower part of Zone $\mathrm{V}$ are characterized by abundant conifer pollen (Abies + Picea - to 59\%, Larixto $8 \%$ ), and also by narrow-leaved species pollen (Betulato $42 \%$, Alnaster - to $10 \%$ and Alnus - to $7 \%$ ) and by little participation from broad-leaved species. In the middle part of this zone the abundance of shrub birch pollen decreased, those of dark coniferous and broad-leaved species pollen increased, and Corylus and Juglans pollen appeared. In assemblages from the upper peat layer, conifer pollen dominates. Broad-leaved species apparently declined. The composition of pollen assemblages suggests that the lower and upper parts of peat in Zone $\mathrm{V}$ accumulated in cool climate conditions and the middle part accumulated in warmer conditions.

\subsection{Gur section}

The Gur peat bog $\left(50^{\circ} 00^{\prime} \mathrm{N} ; 137^{\circ} 03^{\prime} \mathrm{E}\right.$; $35 \mathrm{~m}$ a.s.1.) is located in the northern part of the Middle Amur depression near the mouth of the Gur River, a right-bank tributary of the Amur River. This area is situated in the northern edge of the mixed coniferous broad-leaved forest. The thickness of peat deposits is $345 \mathrm{~cm}$. The lower part of the strata consists of gray, slightly peaty sapropel. 


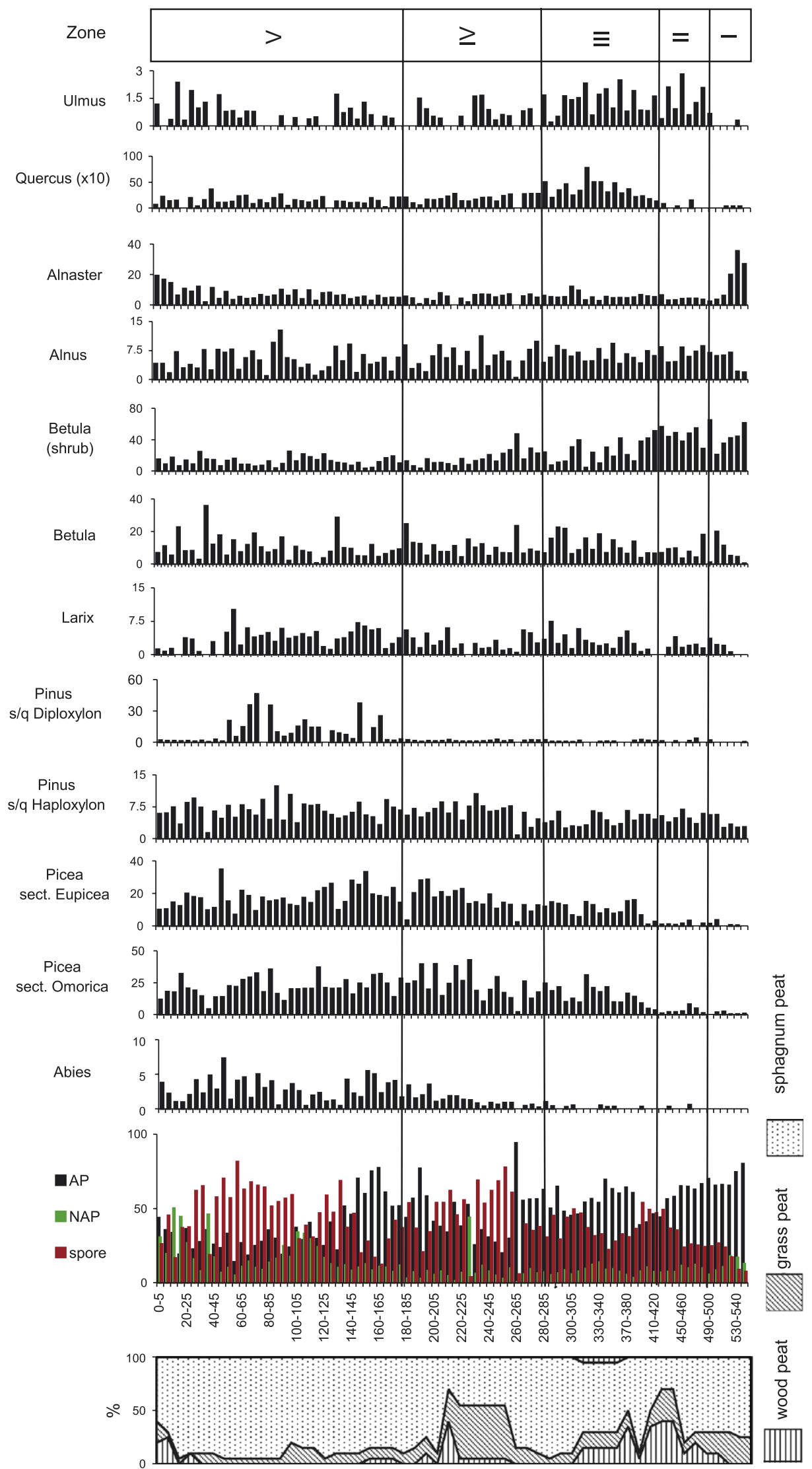

Fig. 2. Palynological diagram and sedimentary succession, Tyapka. 
The overlying stratum consists of grass-woody peat with a different degree of decomposition. The results of palynological analysis are shown in Fig. 3. The diatom assemblages identified in sapropels contain lacustrine species (Cymbella aspera, Stauroneis phoenicenteron and Tetracyclus glans). This complex suggests that accumulation of peat was started when a shallow lake began drying out.

Zone I. $13000-10300 \mathrm{BP}(345-270 \mathrm{~cm})$. Two ${ }^{14} \mathrm{C}$ dates constrain the age over the basal part of the section: $18190 \pm 120 \mathrm{BP}$ (AA-36274) at $345-340 \mathrm{~cm}$ and $12120 \pm 75 \mathrm{BP}$ (AA-36273) at $325-330 \mathrm{~cm}$. The general features of pollen spectra from the lowermost part are: (a) the considerable domination of birch (in general, Betula sect. Nanae) and alder; (b) conifer pollen, with Pinus s/g Haploxylon (Pinus pumila), Picea sect Omorica, Abies and (c) minor spores. Variation in the relative abundance of these pollen groups allow identification of several paleoclimate events, which can be correlated with worldwide warm and cold episodes, including the Bølling, Middle Dryas, Allerød and Younger Dryas. A distinct dust layer at $290 \mathrm{~cm}$ apparently accumulated in very cold and very arid conditions.

Zone II. 10 300-9300 BP (270-245 cm). In the assemblages of the lower part the pollen of narrow-leaved species dominates (Betula sect. Albae - to 23\%, B. sect. Costataeto $8 \%$, Alnaster - to $16 \%$ ). Pollen of Picea sect. Omorica is present in significant amounts (to 17\%). This zone registers the first appearance of broad-leaved species pollen (Ulmus - to 3,3\%, Quercus - to 1\%). A distinct feature of the pollen assemblages and the upper part of Zone II is the prevalence of the spores (to $50 \%$ ) above AP (41\%). Among AP, $57 \%$ belong to shrub birch: Betula sect. Albae and $B$. sect. Costatae are also present. Conifers are represented by pollen of Picea sect. Omorica. The horizon $250-255 \mathrm{~cm}$ was dated at $9590 \pm 50 \mathrm{BP}$ (AA-36949). The composition of the pollen assemblages indicates that peat corresponding to the lower part of Zone II accumulated during slight warming, and that of the upper part during a cooler climate.

Zone III. 9300-8000 BP $(245-190 \mathrm{~cm})$. In the low part of peat strata AP and NAP pollen are present in equal amounts (49-50\%). Shrub birch species $(57-72 \%)$ dominate among AP. The presence of other small-leaved species and coniferous decreased. Even though only single grains of Ulmus were found, this observation is significant. The horizon $225-230 \mathrm{~cm}$ is dated at $9185 \pm 50 \mathrm{BP}$ (AA-36444). The peat corresponding to the lower part of Zone III accumulated in cold climate conditions. The assemblages of the middle part are characterized by a significant increase in broad-leaved pollen dominated by Quercus (to 27\%) with Ulmus and Juglans (to 5.4\%). Single Corylus pollen grains were also observed. This part of peat clearly accumulated in warm climate conditions. In assemblages of the upper part the abundance of AP decreased. The broadleaved species pollen became less and shrub birch became more abundant. This shift in pollen assemblages indicates a change to cooler climate.
Zone IV. 8000-5000 BP (190-120 cm). The assemblages of the low part layer are characterized by prevalence of AP (to $73 \%$ ), decreasing of NAP $(7 \%)$ and spores $(20 \%)$. In composition of AP group coniferous species appear (Abies - to 6\%, Picea sect. Omorica - to 6\%). The abundance of shrub birch pollen decreased, whereas that of the broad-leaved species increased: Quercus - to 31\%, and Ulmus - to 11\%, also Juglans and Corylus became more frequent than in Zone III. The pollen assemblage indicates climate warming. The horizon $175-180 \mathrm{~cm}$ is dated at $7675 \pm 45$ BP (AA-36948). In the middle part of Zone IV, an increase of NAP group (to $20 \%$ ) and the decrease of AP and spore groups are observed. The role of conifers (Picea sect. Omorica - to 9\%, Abies - to 2\%) and that of shrub birch increased in AP composition. The broad-leaved species pollen became less abundant. This peat was accumulated in cooler climate conditions than the underlying layer. The ${ }^{14} \mathrm{C}$ date $6110 \pm 40 \mathrm{BP}$ (AA-36947) at $155-150 \mathrm{~cm}$ constraints the timing of this change. The overlying layer of peat accumulated at the time of strong warming which occurred at about $5000 \mathrm{BP}$. The pollen assemblage and the ${ }^{14} \mathrm{C}$ date $5050 \pm 40 \mathrm{BP}$ at $125-130 \mathrm{~cm}$ confirm this evidence. The upper part of Zone IV contains the maximum amount of broad-leaved species pollen in assemblages in the entire section: up to $41 \%$ of Quercus, $10 \%$ of Ulmus pollen, $5 \%$ of Juglans, $6 \%$ of Corylus and $2 \%$ of Tilia.

Zone V. 5000-2500 BP $(120-50 \mathrm{~cm})$. At the depth of $120-121 \mathrm{~cm}$ a black burnt layer of peat indicative of fire was found. The pollen assemblages are characterized by low AP and NAP counts and higher spore abundance. Among AP the shrub birch pollen dominates (to 50\%). Picea sect. Omorica (to $23 \%$ ) and tree birch (22\%) are also present. The pollen abundance of coniferous and broadleaved species decreased. These pollen assemblages can be interpreted as an onset of colder climate conditions. In the middle part of Zone $\mathrm{V}$ the composition of pollen assemblages is different from that of the lower layer. The AP group increased, broad-leaved species expanded as seen from higher abundance of pollen of Quercus - to $50 \%$, Ulmus - to 5\%, Corylus - to $5 \%$ and Juglans - to $4 \%$. Regional climate must have warmed up at the time of deposition of peat corresponding to the middle part of Zone V. In the upper part of strata AP group (to 25\%) decreased. The abundance of broad-leaved species and spore group (to $55 \%$ ) increased in pollen assemblages. Among tree flora the conifers (Picea sect. Omorica - to $23 \%$, Abies - to 13\%) and the narrow-leaved species (Betula sect. Albae - to $28 \%$, B. sect. Costatae - to $9 \%$, Alnus - to $11 \%$ and Alnaster - to 3\%) dominate. This type of palynological response is characteristic of regional cooling.

Zone VI. 2500-0 BP $(50-0 \mathrm{~cm})$. In lower part of this zone the AP (to $69 \%$ ) group increased and NAP (to $2.5 \%$ ) group decreased in pollen assemblages. In the tree group the dark coniferous species pollen (Pinus $\mathrm{s} / \mathrm{g}$ Haploxylon-to 54\%, Picea sect. Omorica-to 15\%) 


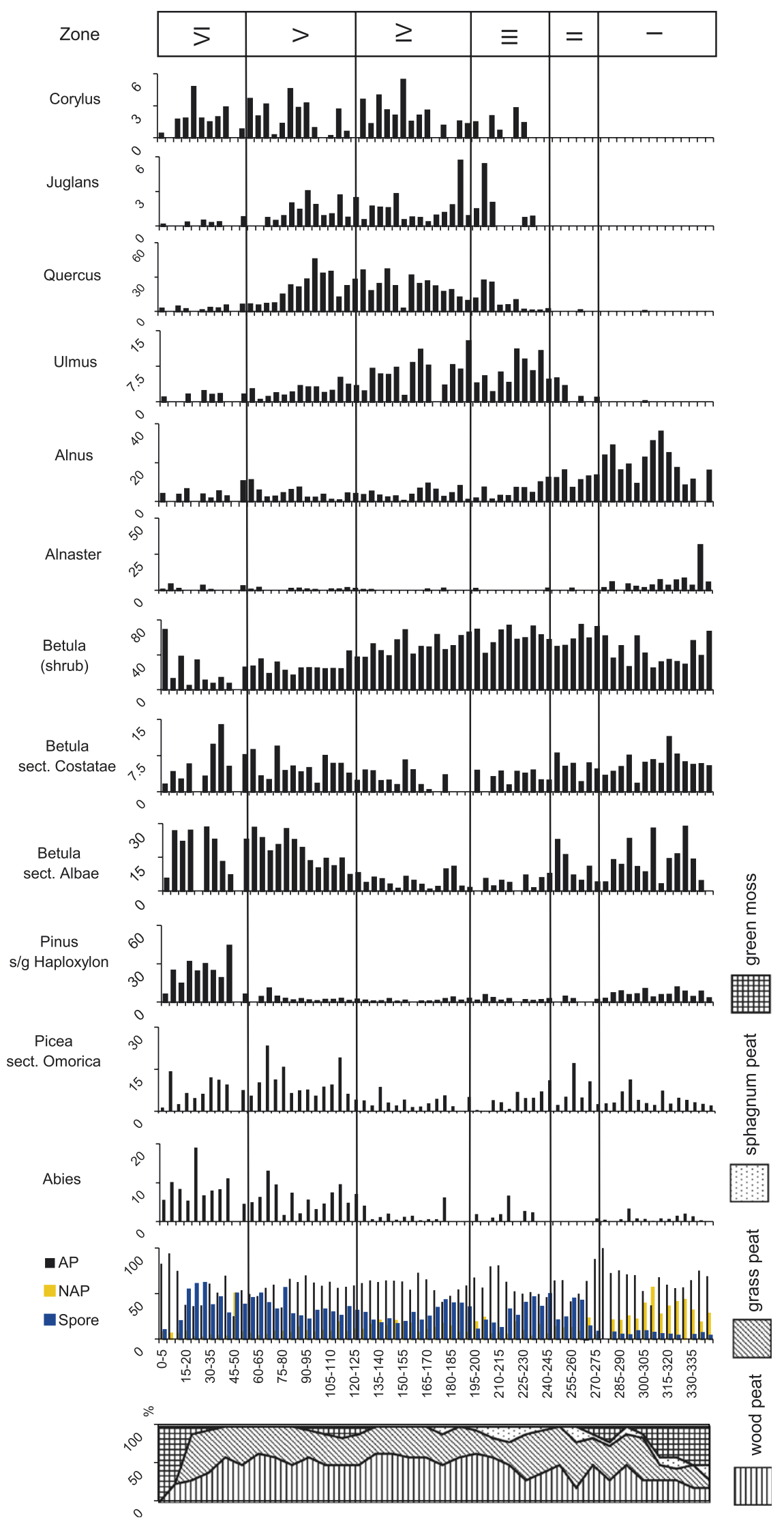

Fig. 3. Palynological diagram and sedimentary succession, Gur. 
increased. The broad-leaved pollen participation became low. The horizon $50-55 \mathrm{~cm}$ was dated at $1140 \pm 35 \mathrm{BP}$ (AA-36945). This interval of peat was accumulated in temperate climate conditions. In pollen assemblages of the uppermost part of the peat section, trees dominate. Most abundant are shrub birch (to 70\%) and conifers (Pinus s/g Haploxylon - to $35 \%$, Abies - to $20 \%$ and Picea sect. Omorica - to 16\%). The role of small-leaved (Betula sect. Albae - to 30\%) increased further, indicating cooler climate conditions.

\subsection{Kiya section}

The Kiya section $\left(47^{\circ} 50^{\prime} \mathrm{N}, 135^{\circ} 40^{\prime} \mathrm{E}, 100 \mathrm{~m}\right.$ a.s.1, $)$ is located in the southern part of the Middle Amur depression, in the interfluve of the Kiya and Khor rivers, both right tributaries of the Amur River. This area is situated in the southern edge of mixed coniferous broadleaved forest. This is the southernmost among the sections in the Lower Amur River basin. The thickness of peat is $210 \mathrm{~cm}$. The very lowermost part of strata consists of lightgrey clay with rare plant remains; the rest upper part of strata contains grass-woody peat of different colours and degrees of decomposition. Diatom assemblages (Eunotia faba, E. incissa, E. pectinalis, Aulacoseira italica, Flagilaria contruens var. venter, $F$. pinnata, Cymbella turgida, Gomphonema tructatum) identified in the basal clay suggests that accumulation of peat began as a result of drying out of a flood-plain lake. The pollen diagram is shown in Fig. 4.

Zone I. 9000-8000 BP $(210-180 \mathrm{~cm})$. In the lowermost clay interval the abundance of shrub birch pollen reaches $18 \%$. Tree group dominates (to $60 \%$ ) in the pollen assemblages that the base of the peat strata consisting of Ulmus (to 36), Quercus (to 25\%), Corylus (to 2\%), Syringa (to $1.5 \%$ ), Phellodendron - to 1.3\%, and also Betula sect. Albae (to 25\%) and B. sect. Costatae (to 14\%). The pollen of coniferous species is represented by Abies (to 2.6\%), Picea sect. Omorica (to 4\%) and single Pinus s/g Haploxylon. The horizon $205-210 \mathrm{~cm}$ is dated at $8890 \pm 95$ BP (SOAN-4454). This floral shift across clay/ peat transition indicates the existence of a flood-plain lake in cold climate conditions and the initiation of peat accumulation at the time of subsequent warming. The pollen assemblages of upper part of Zone I consist of birch pollen (Betula sect. Albae - to 30\%, B. sect. Costatae - to $16 \%$ and $B$. sect. Nanae - to $24 \%$ ). The concentration of broad-leaved (to $20 \%$ ) and coniferous (to $1 \%$ ) pollen is low, and some broad-leaved species disappeared. These floral changes are indicative of cooling.

Zone II. 8000-5000 BP $(180-120 \mathrm{~cm})$. In the lowermost part of the interval broad-leaved pollen dominates: Quercus-to $38 \%$, Ulmus-to $18 \%$, Juglans - to 8\%, Phellodendron - to $1 \%$. The first Tilia (to 3\%) is registered in the pollen assemblage. The horizon $170-175 \mathrm{~cm}$ is dated at $7965 \pm 85$ BP (SOAN-4453). Probably, climate conditions were warm and relatively arid. The pollen assemblages of the middle part of Zone II are characterized by decreasing Quercus (to 24\%) and Ulmus (to 12\%). Increasing Betula. sect. Nanae (to $23 \%$ ) abundances indicate cooler climate conditions. The upper part of Zone II contains a maximum of broad-leaved pollen: Quercus - to 53\%, Ulmus - to $14 \%$, Juglans - to $14 \%$, Tilia - to $6 \%$ and Syringa - to $1.5 \%$, clearly indicating very warm climate conditions. The abundance of shrub birch pollen decreased to as little as $4.5 \%$. The timing of this floral change is constrained by the date $5410 \pm 70 \mathrm{BP}(\mathrm{SOAN}-4718)$ at $120-125 \mathrm{~cm}$.

Zone III 5000-2500 BP $(120-50 \mathrm{~cm})$. In the pollen assemblages of the lower part of Zone III the abundance of tree and shrub birch pollen increased (Betula sect. Albae - to 13\%, B. sect. Costatae - to 6\%, B. sect. Nanaeto $16 \%$ ) and the abundances of Quercus (to $28 \%$ ), Ulmus (to $11 \%$ ), Juglans (to $3 \%$ ), Tilia (to 1\%) decreased. Likely, climate became cooler. In the middle part of Zone III broad-leaved pollen increased in the pollen assemblages again (Quercus - to 38\%, Corylus - to 4\%, Juglans - to $3,5 \%$, Tilia - to $2 \%$ ) and shrub birch pollen (to $1 \%$ ) decreased. The horizon $95-100 \mathrm{~cm}$ was dated at $3720 \pm 100 \mathrm{BP}$ (SOAN-4752). This interval of peat accumulated at the time of relative warming. In the assemblages of the uppermost part Zone III dark coniferous pollen dominates (Pinus s/g Haploxylon - to 34\%, Picea sect. Omorica - to $9 \%$ and Abies - to 8\%). The abundance of broad-leaved pollen decreased (Quercus-to $11 \%$, Ulmusto $9 \%$, Corylus - to $3 \%$ ).

Zone IV. 2500-0 BP $(50-0 \mathrm{~cm})$. In the assemblages of the upper part of the studied section dark coniferous pollen continues to dominate (Pinus s/g Haploxylon - to 50\%, Picea sect. Omorica - to 6\% and Abies - to 7\%), tree birch species are subdominant (to $30 \%$ ). Concentration of broad-leaved pollen increased somewhat (Quercus - to $18 \%$, Ulmus - to 5\%, Corylus - to 4\%). Probably, climate became less cool. Pollen assemblages of the upper part of the interval are characterized by a change in the group of dark coniferous species. The abundance of Pinus $\mathrm{s} / \mathrm{g}$ Diploxylon (to 14\%) and Picea Eupiceae (to 1.2\%) pollen increased, whereas those of Picea sect. Omorica (to 3.5\%) and Abies (to 3\%) pollen decreased. The abundance of broad-leaved pollen also decreased suggestive of further cooling in the region.

\section{Discussion}

For correlation of the Holocene climate events, data from other investigations in surrounding territories (southern-western part of Okhotsk coast, Sakhalin Island, Kuril Islands, Hokkaido Island) were used. Based on palynology and ${ }^{14} \mathrm{C}$ dates, the changes of paleoenvironment of the Lower Amur River basin can be interpreted.

\subsection{Late Pleistocene}

Extensive peat accumulation begun in the early Holocene $(9000-10000 \mathrm{BP})$. Gur section is the only one among 


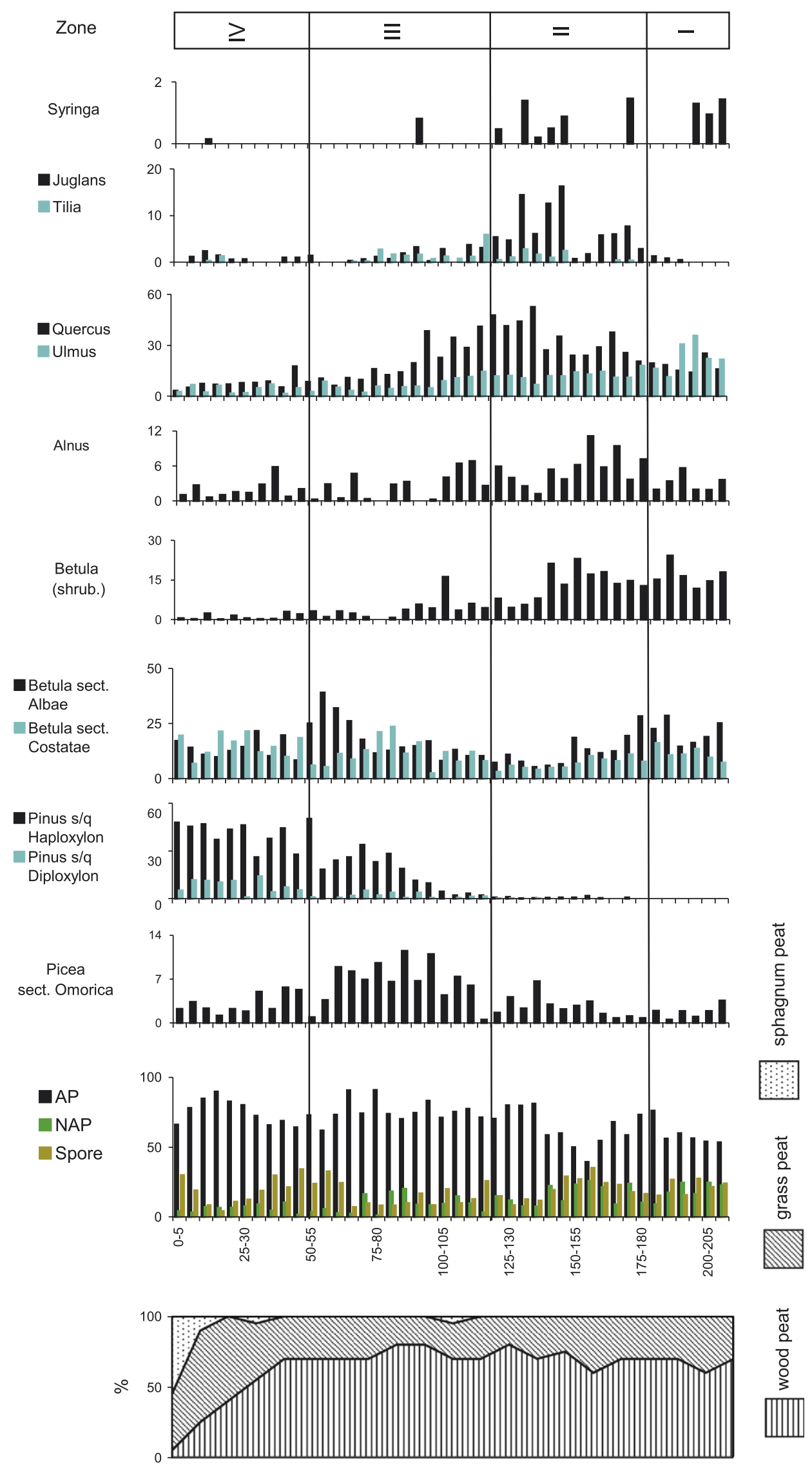

Fig. 4. Palynological diagram and sedimentary succession, Kiya. 
the studied sites where peat accumulation started as early as Late Pleistocene (between 12000 and $13000 \mathrm{BP}$ ) (Korotky, 2002; Bazarova and Klimin, 2001; Klimin et al., 2004). The local relief and hydrologic conditions resulted in swamping of the Gur River mouth area, which was occupied by a large shallow lake before swamping. At the end of the Late Glacial, 13000-10300 BP, during cold episodes, such as the Middle Dryas and Younger Dryas in Europe, the Lower Amur River basin was mainly occupied by shrub birch-alder forests with tree birch and rare Pinus pumila. During warm events, corresponding to the Bølling and Allerød, the role of tree birch-alder forests with rare coniferous species increased. In contiguous areas (southern-western part of Okhotsk coast) rare birch forests with alder and shrub birch were present (Pushkar et al., 1981). On the western coast of Sakhalin Island, shrub forest tundra was widespread (Khotinsky, 1977). On the southern-eastern part of the island, shrub birch-alder forests were present (Mikishin and Gvozdeva, 1996). On Hokkaido Island ca. 11000-10000 BP, the climate conditions were very cold and arid and rare larch forests existed (Igarashi et al., 2001). The Younger Dryas, the last cold event of the Last Glacial, was not only cold but also very dry. In the Gur section a dust layer was found at the depth of $290 \mathrm{~cm}$. This dust was transported from Inner Mongolia as a result of increased winter monsoon intensity.

\subsection{Early Holocene}

At the beginning of the early Holocene (10300-9300 BP) climate conditions became somewhat warmer, allowing the expansion of birch-alder forests with rare larch and Pinus pumila in the northern part of the Lower Amur basin. Permafrost degradation resulted in swamping of the southern-western coastal area of the Sea of Okhotsk. There were birch-alder forests with spruce and the first appearance of oak and elm on the middle part of the basin. On the contiguous Southern Kuril Islands, Pinus pumila was one of the main landscape components (Razjigaeva et al., 2007). The age boundary of $10300-10000 \mathrm{BP}$ was a turning moment in vegetation development. This time is characterized by a major regional warming associated with high moisture supply as seen from the expansion of forests throughout the region (Kind, 1974). The following cooling (9300 BP) led to disappearance of broad-leaved species from forests throughout the region. These species reappeared during the "Uandi warming" at $8900-8300 \mathrm{BP}$ (Khotinsky, 1977). At that time spruce and rare oak, elm and walnut appeared in larch-birch-alder forests in the northern part of the Lower Amur basin. In the middle part of the basin birch-coniferous-broad-leaved forests were typical. Oak (Quercus mongolica) was very abundant as well as elm, walnut, and hazel. The southern part of the Lower Amur basin was occupied by mixed broad-leavedbirch forests with the presence of spruce, fir and rarely Manchurian pines. The broad-leaved species in forests here were more diverse by comparison with the northern parts of this basin. Amur privet and cork tree appeared at that time. At 8800-8900 BP, the swamping of the interfluve of the Kiya and Khor rivers started. On the Southern Kuril Islands, birch forests with coniferous and nemoral elements were widespread. At the end of the early Holocene (8200-8000 BP) the warm phase was followed by cooling. In the northern Lower Amur basin, this resulted in disappearance of broad-leaved species in forests and the return of tree birch-shrub birch assemblages with larch, and the return of alder. In the southern part of this basin broad-leaved trees became less abundant in forest formations. Peat bogs and surrounding forests were occupied by shrub birch. In the forest formations of the southern part of the Lower Amur basin birch became more abundant, whereas of broad-leaved species declined and privet and cork tree disappeared completely. In forest formations of southern and eastern Sakhalin Island, the abundance of alder increased (Mikishin and Gvozdeva, 1996). In the west-central part of the Island, taiga with prevailing of larch and Pinus pumila was widespread (Igarashi et al., 2000). On the Southern Kuril Islands, cooling resulted in favorable conditions for the development of Pumice pumila and for expansion of larch forests (Razjigaeva et al., 2007).

\subsection{Middle Holocene}

Middle Holocene warming (about 7000 BP) in the north of the Lower Amur basin resulted in the expansion of birch-larch-spruce coniferous forests with infrequent Korean pine, oak and elm. A mixed coniferous-broadleaved forest boundary moved northward and reached the mouth of the Amur River. The northern part of the Middle Amur depression was occupied by birch-dark coniferous forest with oak. In addition, elm, walnut, and hazel were present in forests. Linden appeared in the forest assemblages. In the southern part of this depression, broadleaved-birch forests were widespread with dominant oak and elm. There were also a few cork tree and linden. At about $6000 \mathrm{yr} \mathrm{BP}$, the climate became cooler. In forests at the Amur River mouth, there was less oak and elm but more birch, larch and spruce. In forests of the northern part of the Middle Amur depression, the abundance of oak, elm, walnut and hazel decreased, and that of birch increased. Similar changes happened in forests in the southern part of this depression where the abundance of birch and spruce increased. At this time, temperate broadleaved forests occupied almost all Kunashir Island and Iturup Island on the Okhotsk Sea side (Razjigaeva et al., 2004). On Hokkaido Island dark coniferous species (Picea jezoensis and/or Picea glemnii) were widespread in forests (Igarashi et al., 2001).

The end of the middle Holocene $(5700-5000 \mathrm{BP})$ is characterized by a major expansion of diverse species assemblages in forest formations in the entire Lower Amur River basin. In the northern part of the studied area the presence of oak and elm increased; hazel and walnut 
appeared in the forests. The middle part of the basin was occupied by different broad-leaved species among which oak dominated. Elm, walnut, hazel and linden were present. In southeast Sakhalin Island oak, elm, Manchurian walnut, hornbeam, and maple were in forests (Mikishin and Gvozdeva, 1996). On Hokkaido Island at $5200 \mathrm{BP}$ broad-leaved forests with oak prevailing were widespread (Igarashi et al., 2001). This interval therefore represents the climate optimum of the Holocene.

\subsection{Late Holocene}

Strong cooling (about $4900 \mathrm{BP}$ ) resulted in disappearance of broad-leaved trees in forests near the Amur River mouth. There were birch forests with insignificant spruce. The northern part of the Middle Amur depression was occupied by birch-oak forests with spruce, fir and elm. The boundary of the mixed coniferous-broad-leaved forests moved to the south. In the southern part of the Lower Amur basin the abundance of broad-leaved species decreased and those of conifers (spruce, fir and pine) increased. The following warming about 4200-3200 BP (middle Suboreal thermal maximum according to Khotinsky, 1977) resulted in return of spruce-birch forests with participation of oak, elm and rare Manchurian walnut. The middle part of the basin was occupied by spruce-broadleaved forests and the southern part by Korean pinebroad-leaved forests. During the following cooling (3200-1800 BP) larch-birch-spruce forests with pine and alder expanded along the southern-western Okhotsk Sea coast. In the northern part of the Middle Amur depression spruce-fir forests were widespread. The southern part of this depression was occupied by Korean pine-fir-broadleaved forests. At this time southeast Sakhalin Island was occupied by fir-spruce and birch-alder forests (Mikishin and Gvozdeva, 1996). Cool-temperate broad-leaved forests occupied the Okhotsk Sea side of the central part of Iturup Island (Razjigaeva et al., 2002). In the uplands of Hokkaido Island dark coniferous forests consisting of larch, spruce, pine and fir were widespread (Igarashi et al., 2001). Slight warming at $1800-800 \mathrm{BP}$ resulted in increasing of Korean pine, fir, oak and elm in composition of larch-birch-spruce forests in the northern Lower Amur basin. In the middle part of this basin Korean pine-fir forests with spruce, birch and broad-leaved species were typical. The southern part was occupied by Korean pine-broad-leaved formations with the presence of fir and birch. At the end of the Holocene, climate became cooler and resulted in the expansion of larch-birch forests with participation of alder in the southern-western Okhotsk Sea coast. The presence of dark coniferous and broad-leaved species decreased. Rare oak and elm survived only on some southern mountain slopes. The middle part of the Lower Amur basin was occupied by dark coniferousbirch forests with oak and elm. In the southern areas Korean pine dominated in forest formations accompanied by birch, spruce, fir, oak and elm.

\section{Conclusion}

New palynological and radiocarbon data from peat sections in the Lower Amur River basin reflect the dynamics of environment development at the end of the late Pleistocene and the Holocene. Changes of climate and the reaction of the vegetation formations to climate fluctuations were reconstructed across the Lower Amur basin. The extensive peat accumulation in the studied areas began in the early Holocene (9000-10000 BP). The Gur section represents the most complete terrestrial record of the Russian Far East. Data allows reconstruction of the following regional landscape changes: existence of shrub birch-alder forests during warm events corresponding to the Bølling and Allerød in Europe, and the tree birch-alder forests with rare participation of coniferous species during cold episodes, such Middle Dryas and Younger Dryas.

During the Holocene, there were three warm periods in the Lower Amur basin: (a) in the early Holocene (8900-8300 BP); (b) in the middle Holocene (5000-5700 BP) and (c) in the late Holocene $(3200-4200 \mathrm{BP})$. A major expansion of diverse species in the forest formations in the entire Lower Amur River basin occurring at 5000-5700 BP. Data on study of peat sections show that late Pleistocene and Holocene paleoclimate events and paleoenvironment changes in the Lower Amur River basin were correlative with global climate changes.

\section{Acknowledgements}

This study was supported by projects of RFBR-JSPS 0505-66942 and FEB RAS. We thank A.A. Prokopenko for improving the language and organization of the manuscript.

\section{References}

Bazarova, V.B., Klimin, M.A., 2001. Radiocarbon chronology of the Holocene events recorded from peat-bogs in the continental southern Far East of Russia. In: Kasyanov, V.L., (Ed.), Report of the International Workshop on the Global Change Studies in the Far East. Dalnauka Publications, Vladivostok, pp. 42-49.

Igarashi, Y., Sagayama, T., Higake, T., Fukuda, M., 2000. Late quaternary changes in Central and North Sakhalin, Russia. Journal of Geography 109 (2), 165-173.

Igarashi, Y., Igarashi, T., Endo, K., Yamada, O., Nakagava, M., Sumita, M., 2001. Vegetation history since the Late Glacial of Habomai Bog and Ochiishi Cape Bog, Nemuro Peninsula, eastern Hokkaido, north Japan, Japan. Journal of Historical Botany 10 (2), 67-79.

Khotinsky, N.A., 1977. Holocene of Northern Eurasia. Nauka Publications, Moscow, 200pp (in Russian).

Kind, N.V., 1974. Geochronology of Late Anthropogene by Isotope Data. Nauka Publications, Moscow, 256pp (in Russian).

Klimin, M.A., Kuzmin, Y.V., Bazarova, V.B., Mokhova, L.M., Jull, A.J.T., 2004. Late Glacial-Holocene environmental changes and its age in the Lower Amur River basin, Russian Far East: Gursky peatbog case study. Nuclear Instruments and Methods in Physics Research B 223-224, 676-680.

Korotky, A.M., 2002. Pollen characteristics and radiocarbon dates of Last Quaternary deposits of Russian Far East. In: Anderson, P.M., Lohzkin, A.V. (Eds.), Last Quaternary vegetation and climates of 
Siberia and Russian Far East (pollen and radiocarbon data base) NESC FEB RAS Publications, Magadan, pp. 257-369.

Korotky, A.M., Lobanova, L.A., 1983. Rates and conditions of Holocene peat accumulation on Far East. In: Pushkar, V.S., Korotky, A.M. (Eds.), Paleogeographic Analysis and Stratigraphy of Far East Anthropogene. FESC AS of USSR Publications, Vladivostok, pp. 109-119 (in Russian).

Kushev, S.L., 1936. Geomorphologic Materials of Lower Amur River Valley. Materials of Institute of Physics Geography 23. AS of USSR, Leningrad, pp.110-119 (in Russian).

Mikishin, Yu.A., Gvozdeva, I.G., 1996. Environment Development of Southern-Eastern part of Sakhalin Island in Holocene. FESU Publications, Vladivostok, 130pp.

Mikishin, Yu.A., Petrenko, T.I., Gvozdeva, I.G., Razova, G.G., 1987. Stratigraphy of Chlya Lake Terrace Deposits. In: Markevich, V.S. (Ed.), Palynology of East of USSR. FESC AS of USSR Publications, Vladivostok, pp. 94-101 (in Russian).

Minkina, Ts.I., Fyodorova, R.V., Fyodorova, S., 1936. Exchange of forests and history of peat bog development in Far East district by pollen data. Soviet Botany 4, 17-24.

Petrov, Y.S., Novorotsky, P.V., Lenshin, V.T., 2000. Climate of Khabarovsk District and Jewish Autonomic Region. Dalnauka Publications, Vladivostok-Khabarovsk, 174pp. (in Russian).

Prozorov, Y.U.S., 1974. Bogs of Lower Amur River Depressions. Nauka Publications, Novosibirsk, 211pp. (in Russian).

Pushkar, V.S., Okovitaya, N.A., Kulakov, A.P., Karaulova, L.P., 1981. New data of Holocene stratigraphy and paleogeography of northern-western area of Okhotsk Sea coast. In: Korotky, A.V., Shakhgeldyan, I.G. (Eds.), Development of Environment in
Pleistocene. FESC AS of USSR Publications, Vladivostok, pp. 72-81 (in Russian).

Razjigaeva, N.G., Korotky, A.M., Grebennikova, T.A., Ganzey, L.A., Mokhova, L.M., Bazarova, V.B., Sulerzhitsky, L.D., Lutaenko, K.A., 2002. Holocene climate changes and environmental history of Iturup Islands, Kurile Islands, northwestern Pacific. The Holocene 12 (4), 469-480.

Razjigaeva, N.G., Grebennikova, T.A., Ganzey, L.A., Mokhova, L.M., Bazarova, V.B., 2004. The role of global and local factors in determining the middle to late Holocene environmental history of the South Kurile and Komandar islands, northwestern Pacific. Palaeogeography, Palaeoclimatology, Palaeoecology 209, 313-333.

Razjigaeva, N.G., Ganzey, L.A., Belyanina, N.I., Grebennikova, T.A., 2007. Evolution of Shikotan Island landscape in Holocene. In: Baklanov, P.Ya., Ganzey, L.A. (Eds.), Global Change Studies in the Far East. Dalnauka Publications, Vladivostok, pp. 151-164 (in Russian, English abstract).

Sladkov, A.N., 1967. Introduction in Pollen Analysis. Nauka Publications, Moscow, 270pp. (in Russian).

Sokhina, E.N., Boyarskaya, T.D., Okladnikov, A.P., Roslikova, V.I., Chernyuk, A.I., 1978. Section of Newest Deposits of Lower Amur River Area. Nauka Publications, Moscow, 107pp. (in Russian).

Veinbergs, I.G., Voschilko, M.Ye., Shpetalenko, A.M., Stelle, V.Ya., Rose, V.K., 1976. Pollen description of new Late Quaternary sections of southern western Okhotsk Sea coast and shelf. In: Palynology in Continental and Marine Geological Investigations. Zinantne Publications, Riga, pp. 133-149 (in Russian).

Vitvitsky, G.N., 1969. Climate. In: Gerasimov, I.P. (Ed.), Southern Part of Far East. Nauka Publications, Moscow, pp. 70-96 (in Russian). 